University of Nebraska - Lincoln

DigitalCommons@University of Nebraska - Lincoln

USDA National Wildlife Research Center - Staff Publications
U.S. Department of Agriculture: Animal and Plant Health Inspection Service

March 1999

\title{
Candidate Repellents, Oral and Dermal Toxicants, and Fumigants for Brown Treesnake Control
}

Peter J. Savarie

Richard L. Bruggers

Follow this and additional works at: https://digitalcommons.unl.edu/icwdm_usdanwrc

Part of the Environmental Sciences Commons

Savarie, Peter J. and Bruggers, Richard L., "Candidate Repellents, Oral and Dermal Toxicants, and Fumigants for Brown Treesnake Control" (1999). USDA National Wildlife Research Center - Staff Publications. 647.

https://digitalcommons.unl.edu/icwdm_usdanwrc/647

This Article is brought to you for free and open access by the U.S. Department of Agriculture: Animal and Plant Health Inspection Service at DigitalCommons@University of Nebraska - Lincoln. It has been accepted for inclusion in USDA National Wildlife Research Center - Staff Publications by an authorized administrator of DigitalCommons@University of Nebraska - Lincoln. 


\section{Candidate Repellents, Oral and Dermal Toxicants, and Fumigants for Brown Treesnake Control}

Peter J. Savarie

RICHARD L. BRUGgERS

Their he information presented in this chapter was obtained primarily from two computerized literature searches conducted on the Dialog System (Dialog Information Services, Inc.; Palo Alto, Calif.), which covers a wide variety of topics including medicine, environmental sciences, agriculture, and biology. The key word in the first search was the scientific name of the Brown Treesnake, Boiga irregularis. The key words in the second search were repellent, fumigant, toxicant, or control (or any variations of these words) together with the word snake or snakes. In contrast to the research and development of vertebrate pest control agents for rodents and perhaps even birds, there has been no sustained systematic effort to develop chemical control agents for snakes. This is probably because snakes generally are not a chronic pest problem involving large numbers of animals. When control is needed, shooting, clubbing (Spackman, 1972; Roselle, 1978), or trapping (Thompson, 1975) of the individuals involved is usually all that is necessary to resolve the problem. The most sustained effort to develop chemicals to control snakes has been conducted by Japanese scientists attempting to control the Habu, Trimeresurus flavoviridis (Mishima et al., this volume, Chap. 1; Toriba et al., this volume, Chap. 33). This snake poses a human health hazard because hundreds of people are bitten yearly.

Brown Treesnakes have become significant exotic pests in Guam, and there is a need for chemicals to control them (Fritts, 1988; Rodda et al., this volume, Chap. 2). The snakes were probably introduced on Guam via cargo from Papua New Guinea after World War II. They were detected on Guam in the 1950s, became conspicuous in the 1960 s, and are presently distributed throughout the island with population densities in some areas estimated to be several thousand per square kilometer. The Brown Treesnake is considered to be the primary factor responsible for the extirpation of much of the native bird fauna on Guam (Savidge, 1987). Because Guam is a focal point of air and ship cargo traffic in the Pacific, this species could be inadvertently introduced on snake-free islands in the Pacific through shipments of cargo. Brown Treesnakes have been discovered in other Pacific regions (Honolulu, Hawaii; Wake Island; Kwajalein Island; and

SAVARIE, P. J. and R. L. BRUGGERS. 1999. Candidate repellents, oral and dermal toxicants, and fumigants for Brown Treesnake control. Pages 417-422 in Rodda, Gordon H., Sawai, Yoshio, Chiszar, David, and Tanaka, Hiroshi, editors. Problem snake management : the habu and the brown treesnake . Cornell University Press, Ithaca, NY. 534p. 
Saipan), but apparently Guam has the only known reproducing population outside the native range (Fritts, 1987; Fritts et al., this volume, Chap. 14).

Most of the literature published during the 1950s and 1960s on snake toxicants is based on anecdotal information; only in the 1970s did Japanese investigators begin systematic evaluations of chemicals for snake control. The objective of this review is to present information on chemicals that might be appropriate to prevent the dispersal of Brown Treesnakes in cargo and reduce populations in field situations. The ultimate goal is the registration of a chemical(s) for Brown Treesnake control. Five categories of snake control chemicals are discussed below: repellents, oral toxicants, dermal toxicants, fumigants, and commercial insecticides containing pyrethrins.

\section{REPELLENTS}

In the 1950s and 1960s, several organochlorine chemicals-including DDT, chlordane, aldrin, dieldrin, toxaphene, and heptachlor-were categorized as being repellent to snakes (Uhler, 1951; Stickel, 1953; Cummings, 1961; Truman, 1961; Brock and Howard, 1962a, 1962b). The lethal nature of these chemicals is acknowledged (Fitzwater, 1974), and the "repellent" activity was probably a manifestation of the toxicity of these chemicals to snakes. In support of this belief, Hayashi et al. (1978) reported that chlordane had no repellent effect on Habu. Story (1987) even stated that no chemicals are effective snake repellents.

Nonetheless, in 1990, Dr. T's Snake-A-Way (U.S. EPA reg. no. 58630-1) was registered as a snake repellent in the United States. The active ingredients in Snake-A-Way are naphthalene (7\%) and sulfur $(28 \%)$. In trials conducted by McCoid et al. (1993), the Brown Treesnake was not repelled by Snake-A-Way. However, repellent activity was observed in two of five Plains Gartersnakes (Thamnophis radix) tested with pyrethrum smoke generated from a commercial fumigant under laboratory conditions (Secoy, 1979).

\section{ORAL TOXICANTS}

Nicotine sulphate and strychnine are alkaloids that have been used as oral toxicants to control snakes. Nicotine sulphate was first used under field conditions in Manitoba, Canada, to control an "outbreak" of gartersnakes (Thamnophis sirtalis parietalis) by adding it to water contained in metal trays (Flattery, 1949). "Hundreds" of snakes died from the nicotine sulfate-poisoned water. A mixture of 1 part $40 \%$ nicotine sulphate to about 250 parts water has been suggested as being adequate for poisoning the water (Stickel, 1953). Drought conditions would probably facilitate the use of poisoned water for snakes.

Strychnine has been implicated in an unintentional secondary poisoning of a Prairie Rattlesnake (Crotalus v. viridis) that consumed rodents poisoned with strychnine in the field (Campbell, 1952). Egg-eating snakes were killed under field 
conditions when they ate eggs poisoned with two or three medium-sized crystals of strychnine (Bogert, 1948; Uhler, 1951; Brock and Howard, 1962a, 1962b). In laboratory tests, 5 of 12 Gopher Snakes (Pituophis melanoleucus catenifer) died after eating dead or moribund mice that had consumed strychnine bait (Brock, 1965). Snakes also were killed in the laboratory when fed mice that had been heavily dusted with DDT (Brock and Howard, 1962a, 1962b).

\section{DERMAL TOXICANTS}

The organochlorine chemicals discussed under "Repellents" were usually applied on the ground or in structures in which the snakes lived. Consequently, dermal toxicity may also have accounted for the effectiveness of these chemicals; however, specific quantitative snake toxicity data are not available. Matrices known as sponge sand and sticky tape, each containing 5\% chlordane, were found to be effective for killing Habu (Hayashi et al., 1978).

Oshima Lizards (Eumeces marginatus oshimensis) have been tested under laboratory conditions as surrogates for Habu to evaluate several pesticides (Kihara and Yamashita, 1978). This research found that 10\% Diazinon (dimpylate, an organophosphate) or 5\% Lannate (methomyl, a carbamate) were effective lethal agents for Habu when incorporated into an adhesive matrix (Kihara and Yamashita, 1979). The dermal toxicity of bromophos (an organophosphate) was accidently discovered when it was sprayed on snakes for ectoparasite control (Lehmann, 1970).

\section{FUMIGANTS}

Calcium cyanide (which liberates the poisonous gas hydrocyanic acid), chlorine, tetrachloroethane, carbon bisulfide, formaldehyde, and methyl bromide have been listed as effective for fumigation of snakes in dens or burrows (Bogert, 1948; Uhler, 1951; Stickel, 1953; Brock and Howard, 1962a, 1962b). The recommended dose rate for calcium cyanide is 2 ounces for a space not exceeding 5 cubic feet $\left(57 \mathrm{~g} / 0.14 \mathrm{~m}^{3}=0.4 \mathrm{~kg} / \mathrm{m}^{3}\right.$; Uhler, 1951$)$ or 2 ounces $(57 \mathrm{~g})$ per burrow (Bogert, 1948). Dose rates for the other fumigants were not stated. Bond (1984) listed calcium cyanide and aluminum or magnesium phosphide (which liberate the poisonous gas phosphine) as effective for control of snakes but did not include the species and dosages.

The effectiveness of methyl bromide as a fumigant for Brown Treesnakes was evaluated on Guam during September and October 1991 (Savarie et al., in press). Methyl bromide was selected because it is used worldwide as a fumigant for numerous insect pests (Bond, 1984), and is registered by the U.S. Environmental Protection Agency (EPA reg. no. 5785-41). It is a gaseous fumigant used for soil, commodity, horticultural, structural (buildings), and machinery fumigation purposes. It is registered with the EPA at a rate of $4-50 z / 1000 \mathrm{ft}^{3}\left(=4-5 \mathrm{~g} / \mathrm{m}^{3}\right)$ for 
12-18 hours to fumigate rats and mice. EPA-registered application rates of $1-5 \mathrm{lbs} / 1000 \mathrm{ft}^{3}\left(=16-80 \mathrm{~g} / \mathrm{m}^{3}\right)$ for $2-24$ hours are common for pests such as beetles, weevils, moths, and maggots (Anon., 1987). For the Brown Treesnake tests, a simulated nonfood cargo was established, and 18 snakes were randomly positioned in secured cloth bags in a tarpaulin-covered cargo container for each of six fumigation treatments ( $T$ ). Methyl bromide was applied at rates of $0 \mathrm{lb} / 1000 \mathrm{ft}^{3}$ ) $2 \mathrm{~h}$ ( $\mathrm{T} 1$, control); $1.5 \mathrm{lb} / 1000 \mathrm{ft}^{3} / 2 \mathrm{~h}\left(\mathrm{~T} 2: 24 \mathrm{~g} / \mathrm{m}^{3} / 2 \mathrm{~h}\right) ; 1.5 \mathrm{lb} / 1000 \mathrm{ft}^{3} / 1 \mathrm{~h}\left(24 \mathrm{~g} / \mathrm{m}^{3} /\right.$ $1 \mathrm{~h}$ : T3 and T5); $0.75 \mathrm{lb} / 1000 \mathrm{ft}^{3} / 1 \mathrm{~h}\left(\mathrm{~T} 4: 12 \mathrm{~g} / \mathrm{m}^{3} / 1 \mathrm{~h}\right.$ ); and $0.75 \mathrm{lb} / 1000 \mathrm{ft}^{3} / 2 \mathrm{~h}$ (T6: $12 \mathrm{~g} / \mathrm{m}^{3} / 2 \mathrm{~h}$ ).

No control snakes were dead 11 days posttreatment. All snakes died within about 18 hours after T2 and within about 2.5 days after T6. Thirty-two of 36 snakes were dead 3 days after T3 or T5, and all snakes were dead by 11 days posttreatment. One snake died about 4.5 days after T4, and no other snakes died when the trial ended 10 days posttreatment.

These data indicate that snakes can be controlled using currently registered rates of methyl bromide. However, methyl bromide has been identified as an ozone-depleting substance. If its use as a pest fumigant is phased out as recommended (Anon., 1992), an alternate fumigant will have to be developed. Fumigants such as sulfuryl fluoride, aluminum phosphide, and magnesium phosphide (Sine, 1992), which are currently registered for insect pests by the EPA, would be promising candidates for testing.

\section{COMMERCIAL PYRETHRIN INSECTICIDES}

Several commercial insecticides registered in the United States contain pyrethrin chemicals. Pyrethrin chemicals are the active insecticidal constituents of pyrethrum flowers, Chrysanthemum spp., and several potent synthetic pyrethroid chemicals-including fenvalerate, phenothrin, and tetramethrin-have been developed (Budavari, 1989). Anecdotal reports indicate that some of these insecticide products are toxic to snakes, but no published data are available. The route of administration for these products most likely would be dermal, but oral and inhalation routes may also be possible. The natural and synthetic pyrethroid chemicals have good safety records and low mammalian toxicity, but the synthetic pyrethroids are toxic to aquatic organisms (Coats et al., 1989; Eisler, 1992). Commercial insecticides are socially and environmentally acceptable and should be candidates for further testing as oral and dermal toxicants and as fumigants.

Dermally delivered pyrethrin was effective when tested on Oshima Lizards as surrogates for Habu (Kihara and Yamashita, 1978). More recently a Japanese commercial aerosol product containing a synthetic pyrethrin was evaluated as a dermal toxicant for Habu. In general, this product killed snakes in about 3 hours. More detailed information on the testing of this product is presented in Toriba et al., this volume, Chapter 33 . 


\section{CONCLUSION}

Data on several classes of chemicals, including organochlorines, organophosphates, carbamates, and alkaloids, used to control snakes were reviewed to help determine those that might warrant further evaluation as cargo fumigants or as general population reduction toxicants for Brown Treesnake control. Methyl bromide was an effective fumigant overall, but its current use is being reviewed because it is hazardous to the ozone layer of the atmosphere. Other candidate chemicals that may prove to be useful fumigants include aluminum or magnesium phosphide, and pyrethrins. Pyrethrins may also have utility as bait toxicants, but as with any toxicant, a delivery system for this type of application will have to be developed.

\section{ACKMOWLEDGMENTS}

We thank L. Paulik, P. Brown, and M. Seiler for literature searches and retrieval; J. Armer for secretarial help; and C. Ramey and G. Matschke for editorial services. This chapter is a work prepared by employees of the U.S. Government as a part of official duties and, therefore, is not subject to a U.S. copyright.

\section{LITERATURE CITED}

ANON. 1987. Directions for use of the products Metho-O-Gas 100 and MethoO-Gas`. Great Lakes Chemical Corp., 2801 Kent Ave., West Lafayette, IN, USA 47906.

- 1992. Methyl bromide phaseout, labelling, other moves urged. Pest. Toxic Chem. News 21(3):4-5.

Bogert, C. M. 1948. The problem of snake control. How to tell whether the snake at your doorstep is really one of the dangerous ones, and what you can do about it if it is. Nat. Hist. 57:185-188.

Bond, E. J. 1984. Manual of Fumigation for Insect Control. FAO Plant Production and Protection Paper 54. Rome: Food and Agriculture Organization of the United Nations.

BRocK, E. M. 1965. Toxicological feeding trials to evaluate the hazard of secondary poisoning to gopher snakes, Pituophis catenifer. Copeia 1965:244-245.

Brock, E. M., AND W. E. Howard, 1962a. Control methods for snakes. Vertebr. Pest Conf. 1:18-31. . 1962b. How to control snakes. Pest Control 30(8):30, 32, 34, 36.

Budavari, S., ed. 1989. The Merck Index, 11th ed. Rahway, N.J.: Merck.

Campbell, H. 1952. Probable strychnine poisoning of a rattlesnake. Herpetologica 8:184.

Coats, J. R., D. M. Symonik, S. P. Bradbury, S. D. Dyer, L. K. Timson, and G. J. Atchison. 1989. Toxicology of synthetic pyrethroids in aquatic organisms: An overview. Environ. Toxicol. Chem. 8:671-679. 
Cummings, M. W. 1961. Rattlesnake control in residential areas. Univ. Calif. Agric. Exp. Stn. One Sheet Answers, No. 110, Davis, Calif.

EISLER, R. 1992. Fenvalerate hazards to fish, wildlife, and invertebrates: A synoptic review. U.S. Fish Wildl. Serv., Biol. Rep. 2.

FItzWateR, W. D. 1974. Reptiles and amphibians-a management dilemma. Vertebr. Pest Conf. 6:178-183.

Flattery, M. 1949. An effective way to control snakes. Pest Control 17(2):16, 18.

FritTs, T. H. 1987. Movements of snakes via cargo in the Pacific region. 'Elepaio 47:17-18.

- 1988. The Brown Tree Snake, Boiga irregularis, a Threat to Pacific Islands. U.S. Fish Wildl. Serv., Biol. Rep. 88(31).

Hayashi, Y., H. Kinara, and H. TanaKa. 1978. Development of directions for use of chlordane [in Japanese with English summary]. Snake 10:56-59, 99.

Kimara, H., AND H. Yamashita. 1978. The lethal effects of pesticides on reptiles [in Japanese with English summary]. Snake 10:10-15, 93-94.

- 1979. Development of a new type trap with adhesive seat containing pesticides [in Japanese with English summary]. Snake 11:6-10, 119.

LeHManN, H. D. 1970. On the use of the insecticide bromophos for reptile maintenance [in German with English summary]. Salamandra 6:50-52.

McCoid, M. J., E. W. Campbell III, AND B. C. Alokon. 1993. Efficacy of a chemical repellent for the Brown Tree Snake (Boiga irregularis). Snake 25:115-119.

Roselle, R. E. 1978. Snake Control. Univ. Neb. Coop. Ext. Serv., NebGuide G73-13.

Savarie, P. J., W. S. Wood, G. H. Rodda, R. L. Bruggers, ANd R. M. Engeman. In press. Effectiveness of methyl bromide as a cargo fumigant for the Brown Tree Snake (Boiga irregularis). Snake.

SAVIDGE, J. A. 1987. Extinction of an island forest avifauna by an introduced snake. Ecology 68:660-668.

Secoy, D. M. 1979. Investigatory behavior of Plains Garter Snakes, Thamnophis radix (Reptilia: Colubridae), in tests of repellant chemicals. Can. J. Zool. 57:691-693.

SINE, C., ed. 1992. Farm Chemicals Handbook. Willoughby, Ohio: Meister Publishing. Spackman, E. W. 1972. Control of Snakes. Univ. Wyo. Agric. Ext. Serv. Bull. 566.

STICKEL, W. H. 1953. Control of Snakes. U.S. Fish Wildl. Serv., Wildl. Leafl. 345.

STORY, K. 1987. Snakes: Separating fact from fantasy. Pest Control Tech. 15(11):54-5, 58,60 .

Thompson, S. 1975. Snake control. Proc. Great Plains Wildl. Damage Control Workshop 2:174-186.

Truman, L. C. 1961. Birds and other vertebrates. Pest Control 29(9):29-35.

UhLER, F. M. 1951. Facts about Snakes. U.S. Fish Wildl. Serv., Wild. Leafl. 257. 